\title{
THE IMPORTANCE OF THE RISK IN PUBLIC PASSENGER TRANSPORT FINANCING
}

The paper deals with the importance of the risk in financing public passenger transport. The first part analyses the risks affecting financing public passenger transport. These risks can be divided into two basic groups: cost risks and revenue risks. The second part describes the ways of dividing risks between contractual parties. The risk determination in financing public passenger transport is discussed in the last part of the paper.

Keywords: Transport, financing, risk, factor, region, public.

\section{Introduction}

Under current conditions in terms of general economic interest, the public passenger transport services cannot be provided on a commercial basis. Therefore, the mechanisms arise by which the services in public transport are provided even in the time of low demand because it is necessary to ensure the access to basic population's needs such as work, healthcare and education. At present, the following mechanisms are used: the award of exclusive rights to public service operators (the public service operator is considered to be a person who performs transportation, operates the means of transport; and some regulations use the term of carrier), and the grant of financial compensation to public service operators. The mentioned principles are also incorporated in EU legislation [1]. The problem is the determination of financial compensation which includes a share of reasonable profit, mainly in case of the direct award of contract.

One of the reasons for adopting the regulation (EC) No. $1370 / 2007$ was a requirement that the reasonable profit must be dependent on the risk presence [2]. However, the national application of the regulation is different across EU Member States. Based on the public service contracts concluded in the Slovak Republic (SR), the level of reasonable profit and methods for its determination are matters for the agreement between contractual parties - public authority (self-governing regions or cities) and public service operator [3]. The level of reasonable profit is set in range from 3.5 to $5.0 \%$ of economically justified costs in all contracts concluded in the SR to 2011 (e.g. public service contract in the town of Bardejov provides the reasonable profit of $5 \%$ during contract period; the contract is valid until 31.12.2018) [4]. The similar problem can be found also in other EU Member States. For example, in Hungary, public service contract concluded between the authority (Budapest city) and public service operator contains the provisions according to which the level of reasonable profit is a maximum of $4 \%$ of the economically justified costs [5]. In the Czech Republic, the government decree determining reasonable profit at the maximum level of $7.5 \%$ from operating assets per year was adopted in 2010 [6].

The reasonable profit must depend on level of risk-taking. However in practice, it is determined as a percentage of economically justified costs. But this method is not correct, because the operator who efficiently manages and achieves lower costs, also achieves a lower level of reasonable profit in comparison with the operator who provides comparable performance but at higher costs. Public funding should be dependent on the risk that is borne by the public service operator. From this reason, the objective of the paper is to determine the relationship between the risk existence and financing public passenger transport from the position of public authorities.

\section{Analysis of the risks affecting the financing public passenger transport}

Several authors deal with the risks and their distribution between operator and authority (e. g. Stanley, J., van de Velde, D.; Henscher, D. A, Stanley, J. van de Velde, D.). According to

\footnotetext{
* Milos Poliak, Stefania Semanova, Peter Varjan

Department of Road and Urban Transport, Faculty of Operation and Economics of Transport and Communications, University of Zilina, Slovakia,
} E-mail: milos.poliak@fpedas.uniza.sk 


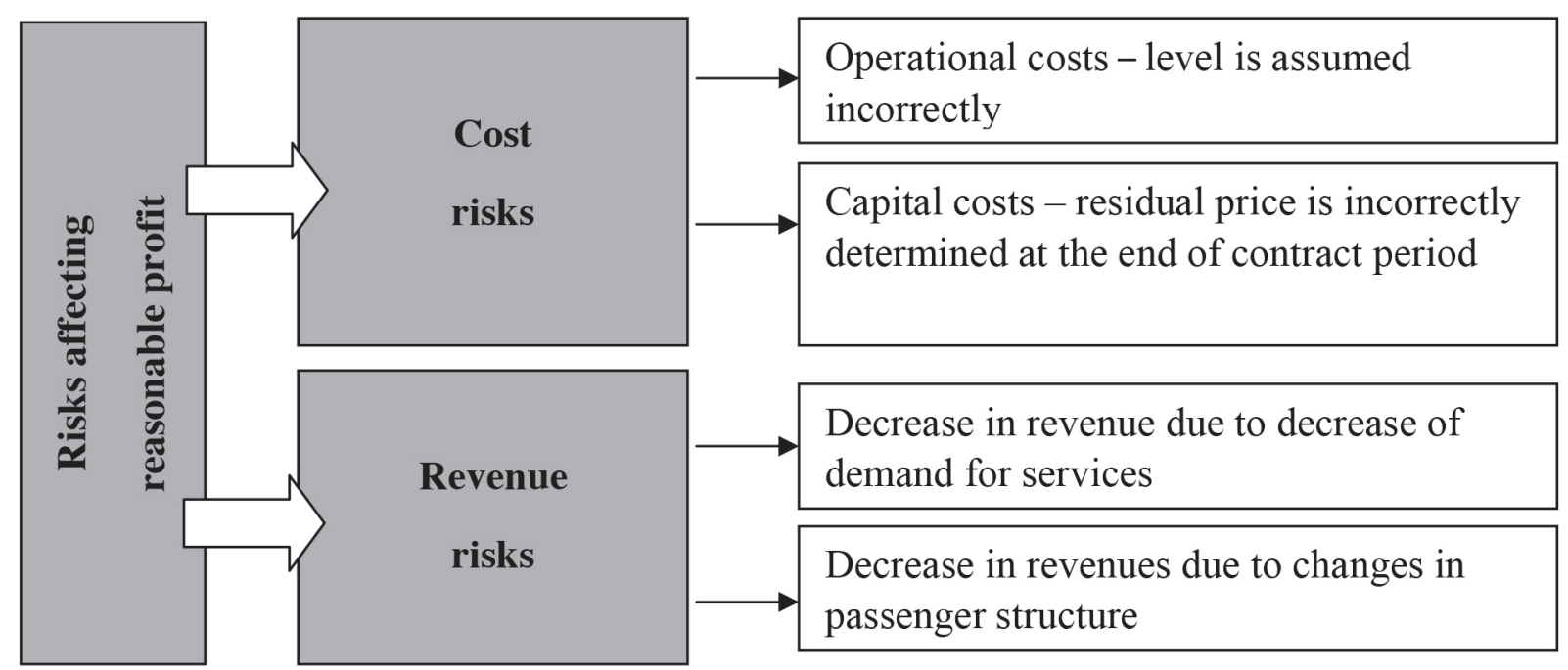

Fig. 1 Classification of the risks affecting the reasonable profit [10]

their studies, the risks should be divided into two groups - cost and revenue risks [7], [8] and [9].

\subsection{Cost risks}

Cost risks are related to the cost calculation when contracting public service contracts. In these contracts, it is necessary to agree on a price for realized performance. The price consists of the costs and profit of operator. When operators assume cost risks, it is necessary to determine a range of realized performance during contract period and economically justified costs per unit of realized performance in public service contracts. The cost risks can be divided into two groups [9]:

- operational cost risks - the risks that are related to the difference of the expected costs calculated and the actually observed costs after performance realization. The reasonable profit must depend on an allocation of this risk. When the operator does not assume the risk and after realization of performance he proves eligibility of costs to public authority for the purpose of compensation, the operator takes no cost risk for the performance realization. In the case that the agreed unit costs in public service contract are final, the operator assumes the cost risk and this should be reflected in appropriate level of reasonable profit. The operational cost risks can be divided into:

O external operational cost risks - the risk that cannot be influenced by the operator at all (e.g. cost increasing due to flooding streets in the event of natural disasters). This group can also include the risk which can be influenced by operator indirectly or only in a small extent (e.g. changes in energy prices during the contract period, change of employees' costs, and etc.),

O internal operational cost risks - the risk that can be influenced by the operator, e.g. the costs of maintaining of vehicle fleet (the operator can decide on the maintenance process in order to avoid failure of vehicle and higher costs),

- investment cost risks - the risks that are related to the difference of the anticipated life of the fixed assets of the operator. While providing public passenger transport it is primarily the means of transport and infrastructure (e.g. bus and tram stops, tram tracks, and etc.). The reasonable profit must depend on which party assumes the risk of the difference of actual net book value of fixed assets at the end of a contract period compared to anticipated net book value.

\subsection{Revenue risks}

Revenue risks are associated with the difference between the expected revenue from an operation of public passenger transport and the revenue actually achieved at the end of contract period. Revenue risks can be borne by either public authorities or operators and in this regard there must be appropriately set a profit level of the operator. When the authority assumes the revenue risk, then a contractual relationship between the authority and the operator which sets a compensation for realized performance is based on following formula:

$$
\mathrm{K}=(\mathrm{NJ}+\mathrm{PZ}) * \mathrm{RV}-\mathrm{V}(€)
$$

where:

$\mathrm{K}$ - compensation to operator from authority, 
$\mathrm{NJ}$ - costs per unit of realized performance,

$\mathrm{PZ}$ - reasonable profit for operator expressed per performance unit,

$\mathrm{RV}$ - realized performance,

$\mathrm{V}$ - revenues achieved when realizing performance.

When there are agreed final costs per unit in public service contract, which cannot be changed during a contract period, the cost risks are fully borne by the operator. The revenue risks are borne by the authority. This means that if operator's revenue is decreasing, the compensation from authority's side is increasing.

When the operator assumes the revenue risk, in the contract there is determined in addition to realized performance also absolute amount of compensation which cannot be changed during a contract period. The compensation is based on anticipated costs and revenue while changes in costs and revenue pose a risk of the operator. A part of the compensation is a reasonable profit of the operator resulting from cost and revenue risk of realized performance.

The cost risks are not usually related with interventions of public authorities (with an exception of changes in tax burden of the operator), and currently they are usually transmitted to operators. In the case of revenue risks, it is possible to define influence of public authorities on revenue risks; the risks can be divided into two groups:

- revenue risk associated with a decrease in demand - it is the risk related to the changes in number of passengers carried when providing public passenger transport. In the case that the authority bears the revenue risk, it is necessary to appropriately involve the operator in compliance with required quality because the amount of the compensation in this case does not depend on the number of passengers carried [10]. In the SR, this risk is very significant because the demand for public passenger transport expressed in passenger-kilometres (pskm) is decreasing annually in road and railway transport.

While the performance of regular bus transport was on the level of 8.4 billion pskm in 2000; in 2011, it was on the level of only 4.611 billion pskm (Table 1). It represents a performance decrease by about $45 \%$. A similar development can be also observed in railway transport where the performance was at the level of 2.87 billion pskm, in 2000. In 2011, performance of railway transport achieved a value only 2.431 billion pskm. This represents a performance decrease by about $15 \%$ (Table 1). Significant decrease in railway transport can be found between
1995 and 2000. Decreasing in demand can be also found in other countries. Changes in demand for public services are elaborated by the authors of studies [12], [13] and [14]. Table 1 shows data from the whole SR, however, the performance decrease is not the same throughout territory of the SR. Therefore, when it comes to the revenue risk associated with a decrease in demand, it is necessary to distinguish territories in which the transport services are operated. The development of number of passengers carried depends to some extent on the interventions of public authorities which can indirectly influence the number of passengers carried through a fulfilling their strategic objectives. The strategic objectives of public authorities can be divided to [15]:

$\bigcirc$ economic - maximizing the effectiveness and efficiency of resource use (e.g. limitations of unused connections, fare increase for less used connections, taxation of passenger cars as a source of compensation for losses of public passenger transport, etc.);

O environmental - minimizing the impact of transportation in a served area (e.g. limiting access of cars at defined time intervals in a serviced territory);

O social - ensuring possibility of mobility for all people, particularly for vulnerable groups of passengers (lower fares for students, pensioners, etc.);

o public - planning transport policy and other policies in a region (e.g. deployment of schools raises a demand for carriage, etc.).

- revenue risk associated with a change of passenger structure - it is the risk of revenue change because of a change of passenger structure. For example, when the selected groups of passengers (students, pensioners) travel with special fares, an increase in number of those passengers while keeping the total number of passengers causes a decrease in total revenue for providing transport services. The good solution is setting an appropriate pricing policy of transport services. However, it is important to monitor the impact of price changes on the demand, which varies considerably for particular groups of passengers [16]. In the SR, the discounted fares known as saver tickets (half price of a full fare ticket) are for young people aged 6 to 15 and students to 26 , and fares known as "other fares" are for [17] and [18] :

○ senior citizens over 70 ( e 0.20 per every $50 \mathrm{~km}$ ),

O severely disabled people (half price of a full fare ticket),

o parents travelling to visit their physically or mentally disabled, chronically ill children nourished in special facilities in the SR (half price of a full fare ticket).

Performance development (in million pskm) in the SR [authors' processing on the base of dates from [11]]

Table 1

\begin{tabular}{|l|c|c|c|c|c|c|c|}
\hline Mode of transport & 2000 & 2005 & 2008 & 2009 & 2010 & 2011 & $\%$ change from 2000 to 2011 \\
\hline Railway passenger transport & 2870 & 2182 & 2296 & 2264 & 2309 & 2431 & $-15 \%$ \\
\hline Regular bus service & 8435 & 7525 & 6446 & 4538 & 4436 & 4611 & $-45 \%$ \\
\hline Urban transport & 1173 & 1399 & 1370 & 1127 & 1119 & 1172 & $0 \%$ \\
\hline
\end{tabular}


The public passenger transport fare is regulated by public authorities that decide which specific groups of passengers will be entitled to reduced fares; and, therefore, the revenue risk associated with the change in passenger structure can be classified as the risks associated with interventions by public authorities.

Based on the above analysis, it can be stated that the most passengers leaving public passenger transport system are those who have an option of other means of transport, mainly a passenger car. This group consists of the passengers travelling for full fare. Students who usually do not have the option of travelling by passenger car, and they are subjected to compulsory school attendance, remain as the users of public passenger transport. Similarly in case of pensioners, the transition to individual motoring is limited at present. Therefore, the need for increasing public funding can be expected because the current trend of increases in number of passengers travelling with special fares persists and these fares bring lower income for operator in comparison with the full fares.

\section{Risk allocation between contractual parties and impact on financing public passenger transport}

There are several options of risk allocation which are related with three basic forms of contractual relation between authority and operator [9]:

- operator bears no risk - cost and revenue risk is borne by authority that pays the economically justified costs to operator. Those costs are accounted in the end of contract period. This means that the risk from difference between anticipated and actual costs is borne by authority which bears also the risk from difference between anticipated and actual revenue. In this case, the level of reasonable profit of operator should relate only to tie up capital during providing transport services because he bears no risk. ,

- operator bears cost risks - the operator bears the risk from difference between anticipated and actual costs in the end of period and the authority bears the risk from difference between anticipated and actual revenue. In this case, the reasonable profit must contain not only tied up capital but also a reward for taking cost risk,

- operator bears cost and revenue risk - in this case the operator bears the risk from difference between anticipated and actual costs/revenue which are identified in the end of contract period. The authority pays only compensation which is agreed before realized performance to operator. This means that the authority bears no risk. The reasonable profit must include the components related to cost risk, revenue risk, and tied up capital.

The analysis of the risk allocation between operator and authority in selected regions of Great Britain, Norway, Sweden,
Finland, Denmark, Netherlands, Italy, USA, Australia, and New Zealand shows that in practice all the mentioned ways of the risk allocation can be found [19]. The risk can be also divided between contracting parties in a certain share regardless of whether there is cost or revenue risk

- full allocation of complete risk to one of the parties - risk of entire difference between anticipated and actual costs/ revenue is allocated to one of the parties,

- sharing risk by contracting parties - a specific share of risk from difference between anticipated and actual costs/ revenue, is assigned to one of the parties, e.g. each party bears the cost risk of $50 \%$,

- sharing of risk between the parties, taking into account specified constraints - this represents risk-sharing proportionally up to a certain limit (e.g. the operator bears revenue risk up to limit of $500000 €$ and the risk over this limit is shared between contracting parties in the same proportion $-50 \%$ ).

When contracting, the authorities must decide how to appropriatelyallocate the risks between contractual parties (van de Velde, D., Veeneman, W., Schipholt, L. L. and Wallis, I., Bray, D., Webster, H.) [20] and [21]. The risks can have a negative impact on the result of contracting; and therefore, the authorities should consider several facts such as:

- increasing risk increases surcharge to reasonable profit,

- the high level of risk borne by operator can cause a risk of operator's insolvency,

- the higher risk, the lower number of candidates is interested in realization of public transport services.

\section{Risk determination in financing public passenger transport}

Determination of reasonable profit as a percentage of costs is economically incorrect in a regulated sector. The reasonable profit must relate to the risk that is borne by operator in regard with realized performance. This means that the level of reasonable profit must be higher in case of the operator bearing cost and revenue risks in comparison with the operator bearing only cost risks while keeping the same range of performance.

Based on the previous analysis of risk allocation, the level of reasonable profit can be defined as follow:

- operator bears no cost or revenue risks - the risks associated with providing transport services are borne only by authority; and therefore, the level of reasonable profit should relate only to the capital used by operator when providing transport services. A reward for provided capital of operator should depend on profitability level of capital invested in term deposits with guaranteed returns. The reasonable profit in 
management contracts is calculated according to following formula:

$$
\mathrm{PZ}=\mathrm{VK} * \mathrm{k}(€)
$$

where: - PZ - reasonable profit,

- VK - capital invested by operator in regard with providing transport services,

- k - capital profitability,

- operatorbears cost risks - the level of reasonable profit must consist of two parts: the reward for provided capital of operator (the same as mentioned above) and the reward corresponding to the cost risks. The reasonable profit when contracting for public interest and where operator bears cost risk is possible to determine according to following formula:

$$
\mathrm{PZ}=\mathrm{VK} * \mathrm{k}+\left(\sum_{\mathrm{i}=1}^{\mathrm{n}}\left(N_{i} * R_{N i}\right)\right) * \mathrm{RV}
$$

where: - Ni - i's value of cost item of operator in unit expression,

- $\mathrm{RNi}$ - risk of assumed value of i's cost item in percentage expression from cost item value,

- n - number of operator's cost items,

- i - i's cost item of operator,

- RV - realized performance.

It is necessary to defined the way of risk determination of estimated values of individual cost items in relation to reasonable profit. The risk can be calculated by using the relationship for determination of safety surcharge to net premiums. Principle of the safety surcharge is based on the fact that number of insurance events is a binomial variable which can be approximated by a normal one and risk premium is chosen in extent of the standard deviation $\sigma$ according to following formula [22]:

$$
R P=\lambda * \sigma
$$

where: - RP - risk premium,

$-\sigma \quad$ - standard deviation of damage level,

- $\lambda$ - non-negative coefficient depending on the number of insurance contracts.

When determining cost risk in contracting between authority and operator, the value of $\lambda$ coefficient can be assumed equal 1 because there is only one public service contract.

Based on the cost development in 2008, Table 2 shows elaborated cost risks for individual cost items of operator. The analysis is elaborated from the data of the public authorities for suburban bus service in SR by comparing the contractually agreed level of costs in the beginning of contract period and the actual level of costs accounted by operator in the end of contract period. The cost risk is calculated by using the standard deviation in euro per kilometer.
Determination of costs risk within SR conditions in 2008 in $€ / \mathrm{km}$ [author's processing]

Table 2

\begin{tabular}{|l|l|}
\hline Cost item & Standard deviation \\
\hline Fuel & 0.0165 \\
\hline Tires & 0.0030 \\
\hline Other direct material & 0.0272 \\
\hline Wages & 0.0464 \\
\hline Depreciation & 0.0496 \\
\hline Repairs and maintenance & 0.0585 \\
\hline Travel expenses & 0.0048 \\
\hline Payroll levies & 0.0152 \\
\hline Another direct costs & 0.0142 \\
\hline Operating overhead & 0.0235 \\
\hline Management overhead & 0.0187 \\
\hline
\end{tabular}

- operator bears cost and revenue risks - the level of reasonable profit must consist of three parts: the reward for provided capital of operator (mentioned above), the reward corresponding to the cost risks (mentioned above), and the reward corresponding to revenue risks. The reasonable profit when contracting for public interest and where operator bears cost and revenue risks is possible to determine according to following formula:

$$
\begin{aligned}
& \mathrm{PZ}=\mathrm{VK} * \mathrm{~K}+\left(\sum_{\mathrm{i}=1}^{\mathrm{n}}\left(\mathrm{N}_{\mathrm{i}} * \mathrm{R}_{\mathrm{Ni}}\right)\right) * \mathrm{RV}+ \\
& +\left(\sum_{\mathrm{i}=1}^{\mathrm{m}}\left(\mathrm{T}_{\mathrm{j}} * \mathrm{R}_{\mathrm{Tj}}\right)\right) * \mathrm{RV}
\end{aligned}
$$

where: $-\mathrm{j} \quad-\mathrm{j}$ 's group of passengers with the same fare level,

- $m$ - number of passenger groups which are different by fare level,

- Ti - assumed revenue of j's passenger group in unit expression,

- RTi - revenue risk of j's passenger group expressed in percentages.

Determining revenue risk is done by an analogous method such as in case of determining cost risk. Revenue risk is possible to determine at standard deviation level of income change per individual groups of passengersin observed period.

\section{Conclusion}

The reasonable profit in returns for realized performance in public interest must depend on the risks borne by operator. A method for determining reasonable profit as a percentage of costs exists not only in the SR but also in other states. However, thus determined reasonable profit does not motivate the operators to cost savings and it is also inconsistent with EU policy. Despite the fact that several authors defined existing risk in providing 
transport services in the form of cost and revenue risk, the method determining reasonable profit dependent on risk-taking has not been developed so far.

The contribution of this paper is processing risk analysis on the cost as well as revenue side within the SR conditions on the basis of known approaches published abroad. The result is also elaborating possible ways of risk allocation between public authorities and public service operators with pointing to their impact. The main benefit of the paper is a procedure for calculating the level of reasonable profit dependent on the risks borne by operator and classification of the risks. Mentioned procedure can be applied in practice in any EU Member State because it is in compliance with EU policy.

\section{References}

[1] Regulation of the European Parliament and of the council (EC) No. 1370/2007 on public passenger transport services by rail and by road and also national regulations of SR (Law No. 56/2012 Z. z. on road transport and Law No. 514/2009 Col. on railway transport).

[2] VAN DE VELDE, D.: A New Regulation for the European Public Transport.Research in Transport Economics 22 (2008), 2008, pp. $78-84$.

[3] Law No. 56/2012 Col. on road transport.

[4] Internal materials of Bardejov town (City bus service contract in the town of Bardejov).

[5] City bus service contract between operator of BKV and the town of Budapest, in 2008.

[6] Decree No. 296/2010 Col. of the Czech Republic On Methods for Determining Financial Model and Defining Maximum Level of Compensation.

[7] STANLEY, J., VAN DE VELDE, D.: Risk and Reward in Public Transport Contracting.Research in Transport Economics 22, 2008, pp. 20-25.

[8] HENSHER, D. A., STANLEY, J.: Performance-based Quality Contracts in Bus Service Provision.Transportation Research A, No. 37, 2003, pp. 519-538.

[9] VAN DE VELDE, D., BECK, A., VAN ELBURG, J., TERSCHUREN, K.: Contracting in Urban Public Transport. Amsterdam. European Commission, 2008, p. 123.

[10] STANLEY, J., VAN DE VELDE, D.: Risk and Reward in Public Transport contracting.Research in Transport Economics 22, 2008, pp. 20-25.

[11] Statistical Office of the Slovak Republic.

[12] CETIN, U., INCE, N., BAYINDIR, P., SAVASANERIL, S.: Route Selection and Scheduling for Urban Public Bus Transportation. Communications - Scientific Letters of the University of Zilina, No. 1, 2013, pp. 19-24.

[13] NOSAL, K.: How to Change the Travellers' Mobility Behaviours? - Examples of Mobility Plans. Communications - Scientific Letters of the University of Zilina, No. 4, 2009, pp. 52-55.

[14] FAITH, P.: Passenger Road Transport Trends in the Slovak Republic. Communications - Scientific Letters of the University of Zilina, No. 3, 2008, pp. 33-39.

[15] STANLEY, J., VAN DE VELDE, D.: Risk and Reward in Public Transport Contracting, Research in Transport Economics 22, 2008, pp. 20-25.

[16] GNAP, J., KONECNY, V., POLIAK, M.: Elasticity of Demand in Public Passenger Transport. Economic J., vol. 7, No. 54, 2006.

[17] Enactment of Authority for rail transport regulation No. 654//2005 Z. z. which determines extent of price regulation in rail transport and price assessments of self-governing regions, which determine maximum prices at national regular bus service on condition that distance between initial stop and final stop is maximum $100 \mathrm{~km}$.

[18] POLIAK, M.: Risk Analysis of Financing Public Passenger Transport. Transport and Communications - Scientific J. 2011-2, ISSN 1336-7676, pp. 125-135.

[19] HENSHER, D. A., WALLIS, I. P.: Competitive Tendering as a Contracting Mechanism for Subsidizing Transport. J. of Transport Economics and Policy, vol. 39, part 3, 2005, pp. 295-321.

[20] VAN DE VELDE, D., VEENEMAN, W., SCHIPHOLT, L. L.: Competitive Tendering in the Netherlands: Central Planning vs. Functional Specifications. Transportation Research A, No. 42, 2008, pp. 1152-1162.

[21] WALlIS, I., BRAY, D., WEBSTER, H.: To Competitively Tender or to Negotiate - Weighing up the Choices in a Mature Market, Research in Transport Economics 29, 2010, pp. 89-98.

[22] CIPRA, T.: Insurance Mathematics-Theory and Practice (in Czech), vol. 2, 2006. 